\title{
Aboriginal Enterprises: negotiating an urban Aboriginality $^{1}$
}

\author{
Sylvia Kleinert
}

In 1952 long time political activist Bill Onus used compensation from a road accident to establish Aboriginal Enterprises, a tourist outlet in Belgrave, on the outskirts of Melbourne. Employing both Indigenous and non-Indigenous workers Aboriginal Enterprises manufactured artefacts and furnishings, imported bark paintings and didjeridus from Arnhem Land and sold a range of other small objects. At a time when assimilation policies expected Aborigines to adopt the ideals and values of white Australians, Aboriginal Enterprises offered a model for cultural maintenance that began to rebuild pride in Aboriginality, contributing toward a new urban Aboriginal presence in Melbourne. Yet despite its success, Aboriginal Enterprises is almost completely overlooked in the history of Aboriginal art in south-eastern Australia. With colonisation Aboriginal people in south-eastern Australia were incorporated within the uneven power relations of a settler society. From the outset they engaged in barter and trade, drawing from their own cosmologies, stories and histories and selectively incorporating from colonial genres. For Aboriginal people, participation in tourism through the production of artefacts and cultural performances was an expression of continuing attachment to their own culture often carried out in opposition to government policies of assimilation. However the narrowly ethnographic concerns of museums viewed the stylistic hybridity and commodification of these objects as evidence of acculturation and cultural decline. This scholarly response imposed an enforced silence on the history of Aboriginal art in the south-east such that, even today, a lacunae exists from the drawings of William Barak and Tommy McRae in the late nineteenth century to the emergence of a contemporary 'urban' Aboriginal artistic expression in the 1970s and 1980s - a period of silence that coincides precisely with the implementation of assimilation policies aimed at rendering Aborigines invisible.

By considering the cultural production of Aboriginal Enterprises in the light of recent debates in cross cultural discourse and the wider socio-political context of colonisation, this paper intervenes in this apparent historical absence to argue for a dynamic and resilient presence in south-eastern Australia. My research

1 An earlier version of this paper was presented at the AIATSIS National Indigenous studies conference, 'Perspectives on urban life: connections and reconnections', 29 September-1 October 2009. In this paper I draw upon doctoral research undertaken in the south-east and I acknowledge the contribution of Lin Onus, Alma Toomath, Albert Mullett, Bindi Williams and Paula Kerry. This paper has benefited from the insightful comments provided by two anonymous referees. 
shows that for ethnic minorities entangled in colonial power relationships, the visibility politics of tourism provides a critical insight into the representation and recognition of Aboriginal identities within the wider framework of the nation state. The ambiguities and tensions that arise around issues of authenticity and tradition as Aboriginal and non-Aboriginal alike engage in processes of collaboration, adaptation and appropriation suggest the saliency of this study to postcolonial debates on tourist art.

\section{Tourism and commodities in a postcolonial world}

Tourist art can be seen as a new mode of production that arose in response to the incorporation of Indigenous people within the globalising forces of colonisation. ${ }^{2}$ Worldwide, it is argued, the cultural production of Indigenous communities expanded in response to their historical experiences and the changing interests of colonisers. ${ }^{3}$ In Australia Aboriginal tourism has its origins in nineteenth and twentieth century missions and reserves such as Ramahyuck (Lake Wellington), Coranderrk and Lake Tyers in Victoria and La Perouse in Sydney where developments in transport allowed ease of access for recreational visitors from nearby cities. Tourism held a range of meanings for Aboriginal and non-Aboriginal alike: for Aboriginal people participation in tourism represented an important means of 'keeping culture'; for visitors tourism met the desire for an encounter with a primitive other. ${ }^{4}$ Nevertheless Aboriginal people and their culture cannot be disassociated from wider debates on race, representation and colonisation. Tourism was, and is, a complex and contested arena of cultural practice. While it can be shown that participation in tourism is beneficial to indigenous people, it is also consistently misrepresented through the artificiality of the tourist encounter as evidence of colonial domination. In seeking to reconsider the role of tourist art within contemporary debates on cross cultural discourse and the politics of cultural identity, it is important to understand how Aboriginal art has been evaluated and the means by which Aboriginal people have mediated these inscriptions to negotiate a place in modern world.

Recent studies in cross cultural discourse draw attention to the way in which Indigenous art has been evaluated and inscribed within western paradigms. As Nicholas Thomas explains, the ironies and contradictions that arise in the process of recognition for Aboriginality can be seen a part of the 'interplay of dispossession and repossession that defines the history of settler societies' ${ }^{5}$ Ambiguously placed in relation to the nation state, Aboriginal people are constructed through colonial ideologies as part of a distant past or remote

2 Phillips 1998: 3.

3 Ruth Phillips' study of native North American souvenir and tourist art provides a comparable perspective. See Phillips 1998.

4 'Keeping culture' is a term commonly used by many Aboriginal people to describe their engagement in cultural practice implying both cultural maintenance and political determination.

5 Thomas 1999: 12. 
present. ${ }^{6}$ 'Since the first serious studies of [Aboriginal culture] began in the late nineteenth century [Thomas argues] scholars and connoisseurs have generally paid attention only to pieces they regarded as traditional': new forms of Aboriginal art incorporating from colonial genre, styles and techniques - 'often made as tourist souvenirs' - were denigrated as evidence of cultural decline and commodification. ${ }^{7}$ The belief on the part of Baldwin Spencer, Honorary Director of Museum Victoria (1898-1928) that there were no surviving traditions in the south-east created a growing concern with authenticity on the part of curators ensuring that, from the 1920s onwards, Museum Victoria ceased collecting artefacts from the south-east. ${ }^{8}$ As Indigenous writer and artist Julie Gough notes, 'generations of hiatus followed for Aboriginal people'. ${ }^{9}$ Incorporated within discriminatory legislation enacted in the late nineteenth century '[i]ndigenous presence was remodelled in the popular imagination as inexplicable ghosted absence ... a precursor for what would proceed nationally'. ${ }^{10}$ In the meantime, cultural constructions of Aboriginality privileged 'real' Aborigines in northern Australia over Aboriginal people in the south-east who were seen to have 'lost' their culture. ${ }^{11}$

Over the past three or four decades much has changed through the political efforts of Aboriginal people. Aboriginal art is now critically acclaimed, represented in private and public collections of museums and galleries in Australia and overseas - no longer seen as 'primitive art' but as contemporary Indigenous art. And its success as a multi-million dollar industry brings recognition not just for the work of individual artists but Aboriginal culture is also a primary focus of attention for international tourism. Today there is growing recognition for the vitality and dynamism of Aboriginal people and culture and the many complex factors at work in cross cultural exchange generally. Where earlier tourist research gave undue emphasis to the consumer, local studies examine tourism from an Indigenous perspective. ${ }^{12}$ Bennetta Jules-Rosette argues that, as a semiotic sign system, tourist art has its own structural integrity 'both triggered by and autonomous of the consumer response'. ${ }^{13}$ As Howard Morphy notes, the cultural production of Aboriginal people is able to fulfil multiple roles (both internal and external) thereby calling into question western categories that differentiate fine art/ craft, art/ artefact, high art/ popular culture. ${ }^{14}$ Indeed it seems that the artificial nature of the encounter between Aboriginal people and tourists far from determining visitors' expectations of Indigenous people as 'primitive, orderly or doomed', as evidence of superficiality or domination, may in fact act as a 'screen' from closer, more invasive scrutiny thereby leaving valued customs protected..$^{15}$ In seeking

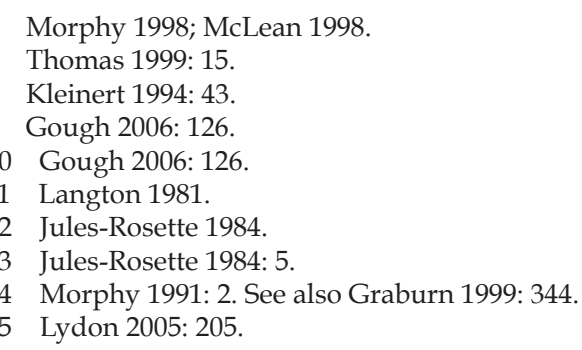


to retrieve recognition for the cultural production of Aboriginal Enterprises, this paper draws upon substantive Aboriginal histories of the south-east by writers such as Bain Attwood, Diane Barwick, Julie Gough, Jane Lydon, Maria Nugent and myself. ${ }^{16}$ In these studies Aboriginal identity is no longer seen in fixed, essentialising terms but as complicated and contingent, 'subject to the continuous "play" of history, culture and power. ${ }^{\prime 17}$ And in contrast to those who misrepresent tourist art as evidence of colonial domination and cultural commodification, these writers highlight the agency of Aboriginal people in the process of cultural exchange. ${ }^{18}$ Jane Lydon's study of Coranderrk notes that "A crucial aspect of the "[Aboriginal] residents" political savvy and their ability to manipulate public debate ... was their self-conscious understanding of how they were represented in white discourse. ${ }^{\prime 19}$ From this model Lydon suggests that encounters between Aboriginal people and tourists can be seen in performative terms as a successful assertion of presence that maintained social cohesion and might also provide a means of status and income. ${ }^{20}$ In this paper I build on and expand these insights moving from an earlier, more restricted historical engagement with tourism on Aboriginal reserves to consider more urbanised, collective initiatives that developed in the context of political transformations taking place in Aboriginal communities in the 1950s and 1960s.

This paper focuses on one particular site of tourist production: Aboriginal Enterprises and its place in a history of domestic tourism in Australia. Obviously my study cannot be inclusive: Aboriginal Enterprises is one of many such initiatives occurring at this time each emerging from particular historical circumstances and with its own distinctive trajectory. Rather I use this paper to consider the radical shifts taking place in the 1950s and 1960s with the increased migration of Aboriginal people into capital cities and the ensuing dialectic between colonial dispossession and the restoration and renewal of cultural identities. Most particularly I am concerned with the place of tourism as a 'meeting ground' wherein both Indigenous and non-Indigenous are involved in processes of adaptation, incorporation and collaboration - and are changed in the process. ${ }^{21}$ The visibility politics of tourism operated in ways that enabled Aboriginal Enterprises to establish a paradigm for a dynamic urban Aboriginal presence that began to negotiate the binarism of an ancient culture in a modern world.

16 Attwood 1989; Barwick 1963; Gough 2006a, b; Kleinert 1994; Lydon 2002; Nugent 2005; Sculthorpe 2000.

17 Hall 1990: 225.

18 See, for example MacCannell 1992; Culler 1988. In the Australian context the pessimism of some commentators misrepresents all Aboriginal art as evidence of colonial domination and commodification (Fry and Willis 1989).

19 Lydon cited by Kleinert 2006: 71.

20 Lydon 2005: 203-205.

21 Thomas 1999. 


\section{Aboriginal enterprise in the city}

For over 15 years from 1952 to 1968, Aboriginal Enterprises provided an important outlet for Aboriginal art and craft in the Melbourne region. Established by Bill Onus (1906-1968) a member of the Wiradjuri Aboriginal nation and a passionate political activist, Aboriginal Enterprises enabled art, as a form of social action, to mobilise culture in the realisation of a political agenda. ${ }^{22}$ While the national goal of assimilation implemented by the Commonwealth Minister for Territories Paul Hasluck championed regulated progress toward assimilation by means of controlled steps to citizenship, Indigenous leaders like Bill Onus and Doug Nicholls - two leading spokesmen of the era - rejected the absorptionist elements in this doctrine. ${ }^{23}$ Instead, Onus and Nicholls declared their commitment to fight for the survival of Aborigines as a distinct group. During the 1950s and 1960s both Onus and Nicholls pursued their agenda through the various forums provided by Aboriginal organisations to articulate their political concerns. As Bain Attwood's archival research reveals, in 1957 Onus developed a programme for the Australian Aborigines' League in which he articulated a desire to promote cultural renewal and reawaken Aboriginal pride. ${ }^{24}$ In the section headed 'Retaining Our Identity as Aboriginals' Onus said:

We wish to emphasize that although overcome by the white community and subjugated for close on 170 years that we have never completely surrendered our ways nor accepted yours. We still reverence [sic] many of our ancient traditions. Even right here in Melbourne, we still are Aborigines at heart... ${ }^{25}$

Onus's cultural strategy had a dual role: to nurture a sense of community spirit among Aborigines through a conscious revival of continuing ancient traditions and to gain recognition for the achievements of Aborigines. ${ }^{26}$ More generally the political programmes developed by Onus and Nicholls sought equality for Aboriginal people. However, discriminatory legislation enacted in the late nineteenth century meant that it was 'politically disadvantageous' for them to

22 For a biography of Bill Onus see Kleinert 2009.

23 In recent years assimilation has generated considerable scholarly debate both as an idea and in relation to its policy and practice from the late 1930s to 1970 (Rowse 2005; Kerin 2005). These insights have given rise to more complex interpretations that explore the multiple meanings and possibilities generated by assimilation. Attwood and Haebich contrast the assimilation policies adopted by government leaders such as Paul Hasluck and AO Neville, Chief Protector of Aborigines in Western Australia 1915-1940, and anthropologists such as AP Elkin - 'a driving force behind policies of social assimilation' and the growing criticism of assimilation in the 1950s and 1960s led by an Aboriginal 'protest tradition' together with anthropologists such as Donald Thomson - and later, Elkin himself (Attwood 2003: 102-104, 202-203; Haebich 1988, 2008: 78). This move can be seen to reflect a general shift from racial to cultural paradigms however discourses of Aboriginality continued to polarise traditional/ urban categories (Rowse 2000; Langton 1981).

24 Attwood 2003: 197

25 Attwood 2003: 197.

26 Attwood 2003: 198. 
seek recognition based on racial or cultural difference. ${ }^{27}$ Acutely aware of the racism confronted by Aboriginal people on a daily basis, Onus and Nicholls intended to achieve equality by appealing to a basic humanitarian concern for equal rights. It seems that the 'meeting ground' provided by tourism enabled opportunities for cross cultural exchange that had salience and meaning for Onus's political agenda - with the potential to become 'an alternative base of political action'.$^{28}$

Aboriginal Enterprises can also be understood in the context of the radical changes taking place in Aboriginal communities at this time. In response to the rhetoric of assimilation, increasing numbers of Aboriginal people chose to leave behind government reserves and rural towns and migrate into the southern capitals. ${ }^{29}$ In so doing they hoped to escape racial discrimination and prejudice and gain access to employment and education. ${ }^{30}$ As art historian Lee-Anne Hall points out, 'colonisation as an imperial project was dependent upon the occupation and control of space' making the relationship with an Indigenous presence 'one of contradiction and unease'. ${ }^{31}$ In Melbourne Aboriginal people encountered prejudice and discrimination, their movements and activities circumscribed by legislation with limited opportunities for employment and a restricted social life. ${ }^{32}$ In response, they drew strength and solidarity from their own initiatives: dances, concerts, theatrical performances, churches and the like. ${ }^{33}$ Similar initiatives sprang up elsewhere: the Coolbaroo Club in Perth, Sunshine Club in Darwin and Boatshed in Brisbane all pursued a committed political agenda aimed at fostering social cohesion and a sense of community amidst the fractured legacy caused by dispossession and diaspora. ${ }^{34}$

Paradoxically, coincidental with assimilation polices that sought to destroy Aboriginal identity, a growing interest in Aboriginal art and culture captured

27 Attwood further argues for the revival and transition in humanitarian thinking from the 1830s and the 1920s and 1930s in the struggle for equal rights (Attwood 2003: 198).

28 MacCannell 1992: 137.

29 Rowse argues that the idea of the 'urban Aboriginal' is 'historically and politically volatile' (Rowse 2000: 171). In Aboriginal history progressive urbanisation in the post war period was initially viewed positively. Rowse undermines these assumptions by drawing attention to the various levels of duress and coercion that prevailed. However it is important not to lose sight of the historical agency of Aboriginal people who chose to 'walk off' from reserves and leave town camps on the outskirts of rural towns to avoid the control wielded by managers, the forced removal of children and prevailing racism and unemployment.

30 Prior to 1939 Aborigines were virtually excluded from the city of Melbourne. Following the Second World War, the Aboriginal population of Melbourne grew to 600 in 1949 (Barwick 1963: 32-36).

31 Hall 2004: 54, 56. Maria Nugent's history of La Perouse in Sydney points up the tenuous nature of its existence; established as a government reserve to disperse Aborigines from Sydney in the 1860s, a Methodist mission 1894-1931 but in 1928 and again in 1964 residents had to resist attempts to remove them from their land (Nugent 2005).

32 Hall 2004; Haebich 2008.

33 See, for example, Corroboree 1949 staged at Wirth's Olympia (now the Victorian Arts Centre) and An Aboriginal Moomba staged in 1951 at Melbourne's prestigious Princess Theatre in protest at the exclusion of Aborigines from the Jubilee celebrations (Kleinert 1994, 1999, 2006).

34 Haebich 2008: 283-299. The Coolbaroo Club also opened an outlet for Aboriginal art and craft (Kinnane and Croft 2003: 17). 
the interest of Australians at large. ${ }^{35}$ During the 1940s and 1950s a series of exhibitions and publications gained national and international recognition for the bark paintings from Arnhem Land and the UNESCO World Art Series celebrated Australia's ancient rock art galleries. But, as Nicholas Thomas argues, the interest in Indigenous art in settler societies is far more pervasive than any narrow focus on the fine arts. ${ }^{36}$ During the 1940s and 1950s the popularity achieved by Albert Namatjira's watercolours made him Australia's best known Aboriginal and a symbol of successful assimilation. And from 1934 onwards, Walkabout magazine portrayed Central Australia (together with iconic images of the Aborigine as noble savage) as the ultimate destination for an expanding tourist industry. At the same time the appropriation of Aboriginal motifs led by Australia's leading modernist, Margaret Preston, and widely advocated by anthropologists Baldwin Spencer, CP Mountford, Leonhard Adam and Frederick McCarthy, was viewed positively as a means of achieving a distinctive national identity. Later in this paper I examine how Aboriginal people engaged in mediating and negotiating these inscriptions in order to meet new demands for representation and recognition. ${ }^{37}$

Aboriginal Enterprises arose from a conjuncture of personal, historical and political circumstances. From the late 1930s onwards Onus played a leading role in political struggles for justice and equal rights. At the same time Onus gained renown for his displays of boomerang throwing at public venues such as Koala Park in Sydney, St Kilda Beach in Melbourne and Healesville Sanctuary in the foothills of the Dandenong Ranges. In the mid 1940s whilst Onus worked as a shipping clerk on the Melbourne wharves, he also made and marketed Aboriginal art and craft from his home at 33 Terry St, Deepdene, a Melbourne suburb. When injuries sustained in a car accident prevented Onus from returning to his employment, he seized the opportunity to open Aboriginal Enterprises.

From the outset Aboriginal Enterprises was extraordinarily successful - a magnet for local and international tourists. Gundidjmara woman Iris LovettGardner, who worked for Aboriginal Enterprises for seven years recalls, 'three or four big buses pulling in' every day. ${ }^{38}$ This was in addition to the many local tourists who travelled by car. Visiting celebrities included the Beatles, Jamaican calypso singer Harry Belafonte, and television stars the Mousketeers from Disney's Mickey Mouse Club. Aboriginal Enterprises met the desire for an encounter with a 'primitive' other, seen as embodying the 'native essence' of a new white nation and a romantic past that was passing away. ${ }^{39}$ The location of Aboriginal Enterprises in the foothills of the Dandenong Ranges, adjacent to a State Forest, served to engender strong associations. The influence which this natural environment had on local, national and international tourists is revealed in the American newspaper The Christian Science Monitor which described how

35 Haebich 2008: 302.

36 Thomas 1999.

37 Phillips and Steiner 1999: 4.

38 Lovett-Gardner 1997: 85.

39 Nugent 2005: 72. 
' $[t]$ he factory is set in one of the most beautiful pockets of the lovely Dandenongs, against Sherbrook Forest where the remarkable lyre bird still largely lives out his mysterious cycle. ${ }^{\prime 0}$ In this response we see how an Aboriginal presence might be conflated with the flora and fauna to engender romantic associations.

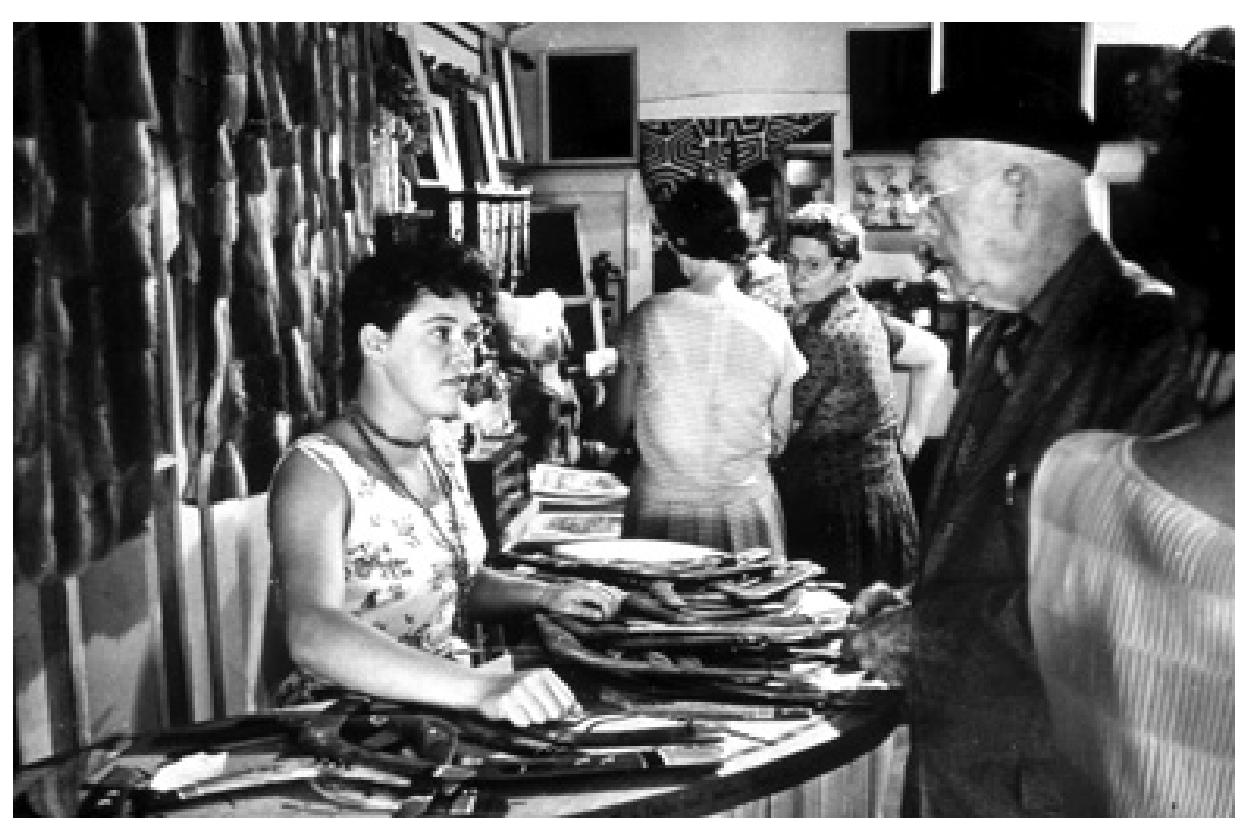

Fig 1. Aboriginal Enterprises, Belgrave, c 1955.

Source: Reproduced courtesy Jo and Tiriki Onus.

To be successful, tourist outlets must offer a range of merchandise and Aboriginal Enterprises sold a range of goods: artefacts and furnishings produced in the workshop at the rear of the shop, kangaroo skin rugs, imported bark paintings and didjeridus from Arnhem Land and a range of other small objects. Whereas Aboriginal artists in remote communities were disadvantaged by their distance from markets and the need to rely on dealers to market their work, in the south-east Aboriginal people were able to maintain control over the production and marketing of their wares. ${ }^{41}$ Like Native American communities involved in a tourist economy, Onus 'did not stay at home waiting for tourists' ${ }^{42}$ Onus actively participated in a modern market economy, opening branches in Port Augusta (South Australia) in 1964 and Narbethong (Victoria) in about 1965. He also shipped merchandise out to tourist outlets in Australia and overseas

40 'Australian seeks boomerang boom', The Christian Science Monitor, 22 October 1955: 7. Lydon documents the promotion of the rain forests of the Dandenong Ranges on the outskirts of Melbourne through the photographs of Nicholas Caire (Lydon 2005: 182-191).

41 Morphy 1980. By contrast Bsumek examines the production of a generic Navaho style created by producers, middlemen and dealers (Bsumek 2008).

42 In her study of American Indians in north-east America, Ruth Phillips identifies a similar entrepreneurial spirit (Phillips 1998: 31). 
to England, Europe and America. ${ }^{43}$ Such initiatives helped support a wider Aboriginal community: in the 1960s Onus assisted Ella Simon to establish the Gillawarra Gift Shop at Purfleet, New South Wales. ${ }^{44}$ Displaying considerable entrepreneurial skills, Onus toured constantly within Victoria and interstate and on one occasion to New Zealand, staging performances of boomerang throwing at various venues: schools, agricultural shows, department stores and special events such as Scout Jamborees, Home Shows, the 1954 visit of Queen Elizabeth II and the 1956 Melbourne Olympic Games. These initiatives built on and expanded the network of connections Onus had established in an earlier era, extending Indigenous use of public space for cultural performances of Aboriginality.

\section{Art as social action}

The economic success of Aboriginal Enterprises was vitally important to negotiating respect and recognition for a dynamic urban Aboriginal presence in south-eastern Australia. But we should not lose sight of its primary value as a form of social action in fostering cultural maintenance and building social cohesion within a broader Indigenous community. Recent studies highlight the way Aboriginal culture follows its own distinctive trajectories reconnecting with the past and creating new representations engaged in spiritual, moral and political terms both in relation to an Aboriginal landscape and a settler colonial society. ${ }^{45}$ Like other similar initiatives in other capital cities, Aboriginal Enterprises claimed the space of the tourist outlet as their own, rebuilding cultural pride in a way that can be seen as a precursor for future developments such as the Boomalli Aboriginal Cooperative established in Sydney in 1987 as a supportive network for Aboriginal artists.

At Aboriginal Enterprises Onus established a model for cultural maintenance by providing training and employment for a great many Aboriginal people. Onus's aim was to employ as many Aboriginal people as possible: family members, refugees who had joined the exodus from Aboriginal reserves and rural towns in Victoria and migrated to Melbourne and visitors from interstate. ${ }^{46}$ Interstate Aborigines included Tommy Cusack from Alice Springs and Nyungar artists Alma Toomath and Revel Cooper (1934-1983) who had grown up on the Carrolup mission in south-west Western Australia. In so doing Onus forged new alliances within the small, relatively closed community of Melbourne Aborigines who retained allegiances to their own regional domain. However, Onus found it impossible to obtain sufficient numbers of Aboriginal workers with the necessary skills. He was forced to also employ non-Indigenous artists: at any one time about half the employees were drawn from the wider community including Paula Kerry, Onus's chief designer plus casual workers, many of whom were

43 Lovett-Gardner 1997: 84-85; Kleinert 1994

44 Kleinert 2009.

45 Morphy 2008; Ginsburg and Myers 2006.

46 Lovett-Gardner 1997. 
European migrant women living on nearby farms who preferred to work from home on a piece work basis. Thus Aboriginal Enterprises represented a dynamic multicultural community where Indigenous and non-Indigenous employees worked cooperatively in a form of cottage industry that involved all aspects of production: manufacturing, demonstrating, designing and sales. From a contemporary perspective it is productive to see a parallel between Aboriginal Enterprises and the Indigenous owned design firm Balarinji established by John Moriarty in 1983, which employs both Indigenous and non-Indigenous artists without in any way compromising its Aboriginality. ${ }^{47}$

Aboriginal Enterprises therefore fulfilled an important role rebuilding traditional patterns of socialisation disrupted through the impact of repressive colonisation. The voice of Indigenous people is testimony to the transformative effect of these experiences on the lives of individuals. Onus's nephew, political activist Bruce McGuiness (1939-2003), reflected upon 'the turning point in his life' at the age of 18 when his uncle Bill Onus 'persuaded him to stop roaming around the country and join him making boomerangs and other artefacts at Belgrave. ${ }^{\prime 4}$ Prior to his employment at Aboriginal Enterprises, McGuiness had worked 'on the wharves, in a circus, in a boxing troupe and as an itinerant labourer. ${ }^{49}$ Onus provided Aboriginal people with a powerful role model. As McGuiness recalls, Bill Onus 'was so proud of being an aboriginal [sic], it was wonderful [he] was a highly intelligent man, and he got me interested in aboriginal [sic] clubs and civil rights movements. ${ }^{50}$ McGuiness's life story makes very clear the impact of Aboriginal Enterprises on individuals.

Onus extended the political reach of Aboriginal Enterprises by touring constantly utilising public space for cultural performances of Aboriginality. Likewise in the mid-1950s, the Coolbaroo Club in Perth extended its reach by holding dances in nearby country towns. Nyungar artist Alma Toomath, for example, met Bill Onus after seeing a display of boomerang throwing at the Esplanade in Perth. In retrospect Toomath recalls:

Bill Onus used to look after me like his own kid. He was just a wonderful person. He used to make things stick in your head. It was his forcefulness made me go and study so he never died really. He was a good bloke who gave you determination and a good cultural way and in those negative times, he made you think positively ... when he saw my paintings he said they were wonderful and it made me think about selling them ... The old boy had a great deal of respect for his culture and you can trust a person like that because you understand the law with Aboriginal people. ${ }^{51}$

47 Moriarty and McHugh 2000.

48 Alan Stewart, 'A stranger in his own land', Herald, 12 December 1970.

49 Alan Stewart, 'A stranger in his own land', Herald, 12 December 1970.

50 Alan Stewart, 'A stranger in his own land', Herald, 12 December 1970.

51 Alma Toomath, interview with Sylvia Kleinert, Perth, 19 August 1992. See also Kleinert 1994: 232. 
By fostering cultural pride, Onus contributed to a process of cultural renewal. Today Aboriginal Enterprises triggers vivid memories for contemporary Aboriginal people who recall wagging school - where they encountered racism and negative Aboriginal stereotypes - to spend the day at Aboriginal Enterprises. This is true for Bill Onus' son, the artist Lin Onus (1948-1996), Gunai elder Albert Mullett and Bindi Williams whose father Harry Williams worked for Bill Onus. ${ }^{52}$ For singer and pianist Margaret Tucker, who performed at weekend concerts in Belgrave, Aboriginal Enterprises was 'a rallying place for all of us Aborigines'.$^{53}$ Thus Aboriginal Enterprises provided a space where Aboriginal people could meet outside the private home when little else was available.

\section{The politics of tourism}

To Aborigines in south-eastern Australia, boomerangs are symbolically important as part of their regional heritage: to non-Indigenous Australians returning boomerangs represent a symbol of national identity. ${ }^{54}$ In a highly original way the cultural production of Aboriginal Enterprises mediated between these two opposed realms and in so doing, negotiated new roles and meanings for Aboriginal artefacts emblematic of Aborigines' changed political, historical and economic circumstances. In the wake of nineteenth-century nationalism, the boomerang underwent a series of transformations to become a ubiquitous symbol of national identity. In the process, curator Steve Miller writes, the boomerang 'became first an Australian rather than a purely Aboriginal signifier, then an international icon of twentieth-century design.' ${ }^{55}$

Boomerang throwing represented a staged 'spectacle of Aboriginality' that was a well established tradition in the south-east. From the nineteenth century onwards, Aboriginal people living on missions and reserves such as Coranderrk, Lake Tyers and La Perouse catered for the interest of visitors by providing demonstrations of boomerang throwing and other cultural practices. As Maria Nugent notes, in her study of tourism at La Perouse, 'local Aboriginal people performed "being Aboriginal" in quite stylised ways that emphasized the exotic, the primitive and the traditional.' ${ }^{56}$ At Aboriginal Enterprises, as at La Perouse, the spectacle of boomerang throwing occurred in various contexts and catered for a range of audiences. When Onus restaged an aspect of traditional Aboriginality and visitors such as Jamaican calypso singer Harry Belafonte, or the then Prime Minister of Singapore, Mr Lee Kuan Yew, mimicked Aboriginal people by learning to throw the boomerang, 'conventional relations were momentarily

52 Kleinert 1994: 230-231.

53 Tucker 1977: 179.

54 Philip Jones argues that in the process of appropriation, the boomerang became stereotyped, losing sight of local regional differences and giving rise to many common misconceptions in the process. For example, the returning boomerang was unknown in Tasmania and northern Australia but held special meaning for Aborigines in south-eastern Australia as part of a distinctive regional heritage (Jones 1992).

55 Miller 2008: 32

56 Nugent 2005: 76. 
suspended and inverted'. ${ }^{57}$ It would seem that an 'imperialist nostalgia' accompanied this conflation of tradition and modernity as Aborigines were inscribed within an essential binary of Stone Age and modernity. ${ }^{58}$ From an Indigenous perspective, however, the boomerang, as a sign of Aboriginality, began to assume a new role separate from its former association with the ethnographic context of museum to accrue broader meanings as part of an evolving living culture. ${ }^{59}$ Viewed as a form of 'culture-making' such performances can be seen as one of the primary means by which Indigenous people negotiate and circulate cultural constructions of identity. ${ }^{60}$

In response to this intensity of interest on the part of the public, Aboriginal Enterprises produced thousands of boomerangs to meet the demand from a domestic and international market. It was reported that Aboriginal Enterprises produced over 20,000 boomerangs annually. With considerable business acumen Bill Onus marketed a range of production that appealed to a diversity of buyers. The best quality boomerangs used blackwood, red wattle or red gum and later, South Australian gidgee. Selecting the wood required considerable expertise and Onus worked with a small team of men to find the roots and elbows necessary for high quality boomerangs. Economic viability prevailed: boomerangs were no longer hand-crafted but manufactured using a band-saw, sander and buff-wheel. Onus also produced a red plastic boomerang made from insulating fibre that was tough, flexible and virtually indestructible in outdoor demonstrations plus small light plywood boomerangs suitable for children.

Such mass production was not in itself a cause for concern but it would lead to questions concerning the authenticity of Aboriginal Enterprises and made the firm susceptible to competition from off shore imports. It also contributed to the marginalisation of women's craft, unable to compete with such mass production and without the status commanded by the boomerang as a symbol of national identity. In 1955 Onus proudly showed a journalist from The Australian Home Beautiful a coiled basket woven by an elderly relative, Sandra Smith, from nearby Healesville using a traditional needle of kangaroo shin bone. ${ }^{61}$ Onus reported that, 'A wholesaler wanted 200 of these, but I could let him have only two, because she takes a week to make a basket. ${ }^{\prime 2}$ Women's fibre baskets would remain marginalised until the $1980 \mathrm{~s}$ when Aboriginal women initiated collaborative intercultural processes of cultural revival.

57 Nugent 2005: 77.

58 Rosaldo cited by Phillips 1998: 137.

59 Such positive representations of Aborigines as part of a dynamic living culture can be usefully contrasted with the campaign materials and films produced by state and federal governments in support of assimilation (Haebich 2008: 143-154).

60 Myers 1994.

61 Hurst 1955.

62 Hurst 1955. 


\section{'He tells the tales of his own people'}

It can be seen that Aboriginal Enterprises marked a transition from an earlier, more restricted historical engagement with tourism on Aboriginal reserves towards more urbanised, collective initiatives. Its success hinged on a genderbased collaborative mode of production that was well understood in Aboriginal communities. While Bill Onus worked with a team of men on the production of boomerangs and furniture items, Paula Kerry, together with other artists including her daughter Helen, Alma Toomath and Harry Williams took responsibility for the decoration of artefacts. Commercial artist Paula Kerry (1923-2008) was therefore a key figure in Aboriginal Enterprises. ${ }^{63}$ Over a period of 15 years Kerry managed production, provided designs for screen prints, decorated boomerangs and other small items and, in Onus's absence, acted as sales manager.

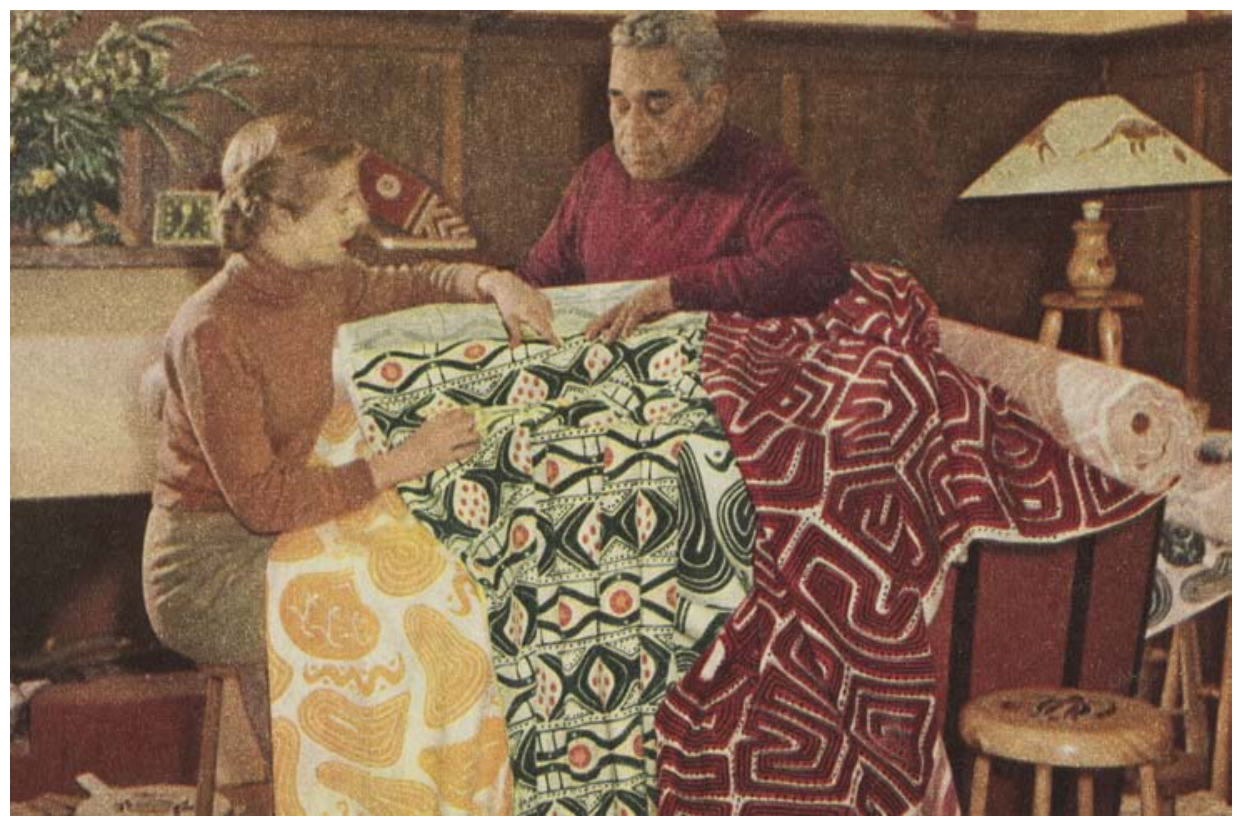

Fig 2. Mr Bill Onus, Melbourne, discusses some prints of his new fabric design with his chief designer, Mrs Paula Kerry, The Australian Home Beautiful, November 1955.

Source: Reproduced with permission of The Australian Home Beautiful, Collection, National Library of Australia.

63 After attending the National Gallery School (possibly part-time) Paula Kerry (later O'Dare) trained as a silk screen designer initially with Vida Turner then with Tubby Grant and Joan Porter whose firm adapted English textile designs for printing in Japan and subsequent resale in Australia. Kerry, together with Geoff Kerry and Ambrose and Phyl Dyson established the Guild Studios in 1949. In the late 1940s Kerry began working freelance for Bill Onus and in 1952 she commenced employment with Aboriginal Enterprises. Kerry's involvement with Aboriginal Enterprises was political in nature. In retrospect Kerry believed that it was the racism and segregation she witnessed whilst working at Peak Hill, New South Wales in the late 1940s which predisposed her to working with Onus. 
In the history of Aboriginal art such collaborative forays between white and black, like that which occurred between Rex Battarbee and Albert Namatjira, and between Geoffrey Bardon and the Papunya painters, are all too rare and tend to be viewed with suspicion as evidence of cultural imperialism. Ian McLean suggests that this negative response has its origins in a Social Darwinist mindset and is continued through the emphasis given to individual self expression that is the basis for European visual traditions by contrast with the communal activity that is central to Indigenous practice. ${ }^{64}$ Most importantly, McLean points out, collaboration may take various forms both authorised and illegitimate. If collaboration 'negotiates something in exchange', he argues, it can also be 'a form of resistance' ${ }^{65}$ Given the paucity of debate in this area it is worthwhile exploring in greater detail the mode of production operating at Aboriginal Enterprises.

I begin by considering a much-reproduced photograph taken in 1952 for publicity purposes prior to the opening of Aboriginal Enterprises. The photograph depicts Bill Onus in discussion with 'Mrs Paula Kerry' within an Indigenised domestic interior where Aboriginal motifs feature in every aspect of the furnishing-including boomerangs displayed prominently on the picture rail. Onus well understood the importance of such representations as a means of gaining recognition for the 'Aboriginal cause'. As Indigenous academic Marcia Langton points out, Aboriginality is a 'field of intersubjectivity ... that is remade over and over again in a process of dialogue, of imagination, of representation and interpretation.' ${ }^{66}$ As such the photograph is a representation of Onus's political goals, at once a denotation of Aboriginal equality and recognition of a distinctive culture. The photograph is also expressive of what Sue Taffe sees as an unusual era of shared purpose and co-operation between Indigenous and non-Indigenous Australians in the decades leading up to the successful 1967 Commonwealth referendum when 90.77 per cent of Australians voted to amend the 1901 constitution. ${ }^{67}$

The appropriation of Aboriginal motifs is central to this Indigenised space - indicative of the argument that in the Australian context, a modernist aesthetic is first taken up in design before the fine arts. ${ }^{68}$ In the 1950s the appropriation of Aboriginal motifs was viewed positively as a means of achieving a distinctive Australian identity: more recently, with growing awareness of the moral and political issues involved in relation to Indigenous intellectual property, appropriation is condemned as evidence of colonial domination. ${ }^{69}$ In response to these generalised assumptions regarding the positive and negative aspects of appropriation Nicholas Thomas suggests that what is required is an exploration for the motivation of particular works and how they were assessed and valued within specific instances of cross cultural discourse. ${ }^{70}$ With regard to Aboriginal Enterprises, the question is raised what are the origins of these designs, to what degree was their appropriation authorised and what was the value placed upon these designs?

64 McLean 2009

65 McLean 2009.

66 Langton 1993: 33

67 Taffe 2001: 20.

68 Stephen et al 2006: 5, 13, 15.

69 Johnson 1996.

70 Thomas 1999: 141. 
To intervene in these debates it is necessary to historicise appropriation to understand the broader context of social conditions and particular circumstances at the time of production. In the first instance it is important to acknowledge that Onus authorised Kerry's use of Aboriginal motifs. Prior to the opening of Aboriginal Enterprises in 1952, Onus paid for Kerry to travel to Alice Springs and Uluru (then Ayers Rock) in Central Australia to expand her knowledge of Aboriginal culture. From a contemporary perspective such out-of-area appropriation would be seen as culturally inappropriate, however Onus's position can be understood in terms of the devastating impact of colonisation. ${ }^{71}$ For Aborigines in south-eastern Australia who had suffered dispossession and unrelenting colonisation, incorporation of Aboriginal motifs from other regions represented a means of cultural revival and a reaffirmation of cultural identity. Distinctions must also be drawn between a contemporary era where policies of self determination offer considerably greater freedom and the restrictions imposed by assimilation policies previously. In retrospect, artist Lin Onus recalled that 'for artists the only role model of the time was Albert Namatjira. Indeed to introduce any element of Aboriginality into one work would have rendered it both unfashionable and unsaleable. ${ }^{72}$

The motivation for these appropriations was therefore quite specific. In my conversations with Paula Kerry she clearly differentiated between her work and that of other artists like Melbourne designer France Burke with whose work she was familiar. Kerry, unlike other non-Aboriginal artists, did not use Aboriginal motifs to achieve a distinctive national identity nor as a personal form of artistic expression. Rather these designs were produced 'for that project ... to promote Aboriginal culture'.$^{73}$ Informed and aware of Aboriginal political struggles for equality and recognition, Kerry took the opportunity provided by interviews in women's magazines to raise humanitarian issues. ${ }^{74}$ She also placed considerable value on the authenticity of her designs - unlike the generalised designs of Margaret Preston and Frances Burke. ${ }^{75}$ For Kerry authenticity meant accurate reproduction of regionally distinctive designs. Indeed Kerry's research led her to use bright lively colours in place of the restricted palette of stereotypical ochre colours employed by many artists as confirmation of their authenticity. Over time she developed various styles based on her research with particular publications: Brough Smyth's The Aborigines of Victoria (1878), Charles Mountford's Art, Myth and Symbolism (1956) and Miller and Rutter's Child Artists of the Australian Bush (1952) which celebrated the emergence of a distinctive school of children's art at the Aboriginal settlement of Carrolup. ${ }^{76}$ In a photograph of Bill Onus and Nyungar artist Revel Cooper, they hold a boomerang decorated in the 'Carrolup' style. Looking at the decoration of the boomerang it is possible to discern Kerry's process of adaptation

71 During research conducted at La Perouse James Bell also found a strong desire for cultural renewal and for information and images to assist in tourist production (Bell 1967).

72 Onus 1990: 15.

73 Kleinert 1994: 238.

74 Auld 1957: 7.

75 For a recent overview of these debates see Edwards 2005.

76 Children's art from Carrolup emerged in the late 1940s under the encouragement of the headmaster Noel White and his wife. At the time this movement created considerable interest and its legacy has since inspired a contemporary artistic expression among Nyungar in south-west Western Australia. For a recent overview of these developments see Pushman and Walley 2006. 
combining motifs from various reproductions: dancing figures, flora and fauna and geometric elements, to create a new design in keeping with the style of the Carrolup School. ${ }^{77}$ In the process the boomerang is transformed. Both artefact and art object, the boomerang operates unambiguously as a sign of Aboriginality. ${ }^{78}$

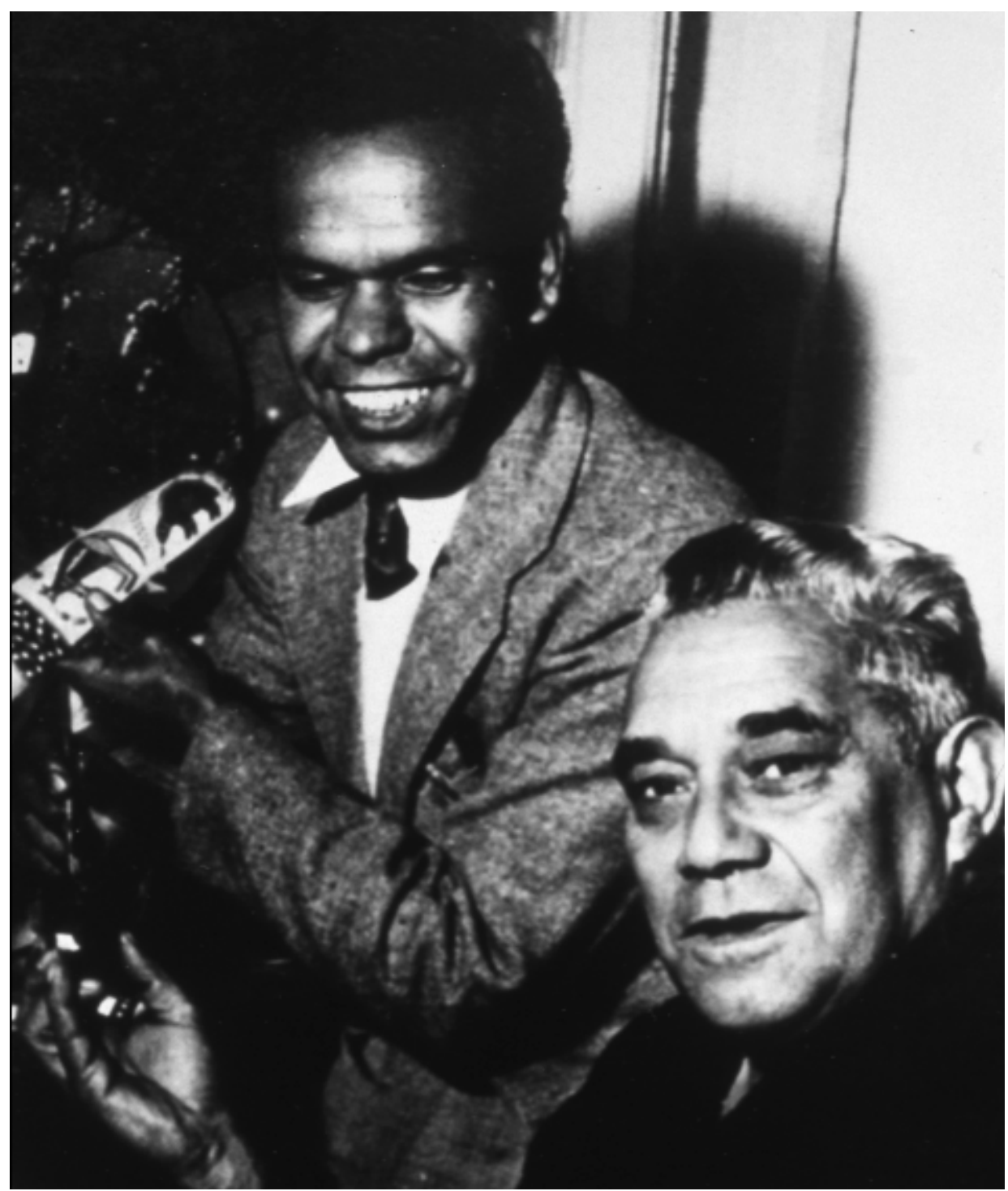

Fig 3. Bill Onus and Nyungar artist Revel Cooper with a boomerang decorated by Paula Kerry in the 'Carrolup' style, late 1950s.

Source: Image courtesy of Australian Institute of Aboriginal and Torres Strait Islander Studies. Alick Jackomos collection, Image number N3767.29a.

77 See for example 'Possum' by Revel Cooper (Miller and Rutter 1952: 48); Plate 13, 'A native corroboree' by Reynold Hart (Miller and Rutter 1952).

78 Burn and Stephen 2002: 255. 
It is clear that Onus well understood issues of authenticity. On a number of occasions he publicly condemned the widespread appropriation of Aboriginal motifs: 'Some goods are being sold bearing figures claimed to be aboriginal [sic] art, but these are simply what the designers consider it should be like', he said. 'We produce the real thing. ${ }^{.79}$ Onus's use of term 'real' indicates his awareness of the differences between Aboriginal and non-Aboriginal value systems. 'Under colonial regimes', Ruth Phillips argues, '[such] acts of articulation constitute a form of resistance that needs to be acknowledged ... for they lead to the highly effective reassertion of Aboriginal concepts of cultural property and replication made in recent years' ${ }^{80}$ What emerges from this discussion is the disjuncture between culturally different ideas about authenticity. Onus was well aware that essentialist paradigms of authenticity evaluated Aborigines against a primitivist stereotype of the noble savage. From an Aboriginal perspective however it can be shown that the labels 'traditional' and 'authentic' are irrelevant. Like Indigenous people elsewhere engaged in the tourist system Onus implemented tactical manoeuvres that played to the primitivist expectations of tourists while maintaining a degree of Indigenous autonomy. For instance the widespread use of tribal names as pseudonyms in some of the cultural production at Aboriginal Enterprises might be seen as reifying a traditional Aboriginality and evidence of authenticity but it can also be seen in a broader context as a reflection of the political transformations taking place in the 1950s and 1960s as an affirmation of cultural identity ${ }^{81}$ Presenting himself as one who could bridge historical and cultural difference, Onus drew upon his cultural knowledge to relay 'the tales of his own people' ${ }^{82}$ In the process Onus regained a degree of control over these designs thereby undercutting the colonial appropriation of Aboriginal motifs.

\section{Modern Aboriginality}

While the cultural production for tourist souvenirs necessarily involves repetition and copying it is important to acknowledge its innovation and creativity. One of the Onus's most creative initiatives was the adaptation of the classic 1950s kidney shape that graced the swimming pools and furniture of many contemporary homes into a boomerang-shaped table. Presented as a set of nesting plywood tables on three tapering metal-capped legs, the tables signalled the modernity of Aboriginal Enterprises design. Like the Balarinji designs on Qantas jets that wing their way round the world, Onus's design effectively conflated the binarism of an ancient Stone Age with a quintessential emblem of modernity.

79 Hurst 1995: 26.

80 Phillips 1998: 58.

81 For evidence of the tactics employed by Aborigines to retain their dignity and autonomy in their interaction with tourists see Attwood 1989: 141-142; Lydon 2005: 186-205; Kleinert 1994: 130-132.

82 Hurst 1955: 26. 


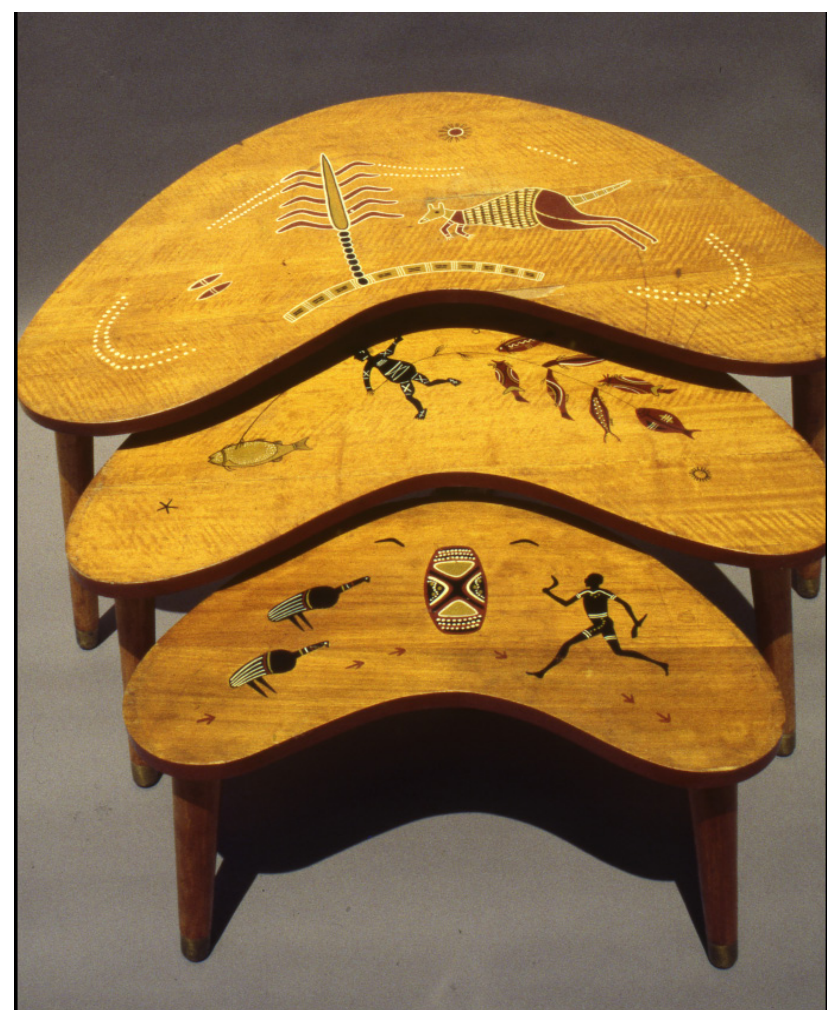

Fig 4. Aboriginal Enterprises set of nesting tables, 1952.

Source: Reproduced courtesy of Jo and Tiriki Onus.

To decorate the tables Kerry deployed various designs. One of the most popular was the Gunbalanya legend of Buppa Piebi, adapted from an illustration in Colin Simpson's Adam in Ochre (1951). The narrative of Buppa Piebi, a rotund and diminutive figure who walked in the waterholes at night spearing fish, is doubly signified, through playful figurative imagery on the table top and by means of text inscribed around the edge of the table. The popularity of this particular image provides an opportunity to consider how Aboriginal Enterprises negotiated relationships with the market place. Recent studies by Ruth B Phillips and Bennetta Jules-Rosette confirm that the process of signification in tourist exchange involves several stages in the selection and development of tourist souvenirs. They argue that the product and the image 'are both triggered by and autonomous of the consumer response: neither entirely dictated by the dominant culture nor were they blind and unmotivated.' 83 Rather Aboriginal Enterprises 'routinely elected to use images and forms that, while innovative, continued to "make sense" within both Indigenous and [non-Indigenous] signifiying systems. ${ }^{\prime 84}$

83 Jules-Rosette 1984: 5.

84 Phillips 1998: 20. 
To illustrate this process it is intriguing to consider the various stages that occurred in the selection and development of imagery at Aboriginal Enterprises. Kerry recalls her first attempts at quality control:

In those early days customers flocked in and bought anything, some of which was stock that was rather awful that had been bought in. Initially I erred on the other side by painting items with what I thought was artistically good, more abstract work and soon found the customers wanted [figures] and easily recognisable Australian fauna i.e. kangaroos and emu etc. ${ }^{85}$

In this passage we see how Kerry modified her own modernist aesthetic in response to the interest of consumers. A parallel for Kelly's experience exists in the response of Pastor Albrecht at the Hermannsburg mission as he struggled to establish a nascent souvenir industry in the 1930s. Albrecht recorded the response of visitors to the introduction of poker-worked images on mulga plaques:

the first pieces where we used the old engravings of tjuringas as a design did not sell. But then one of the natives started working freehand drawings of local animals, palms which appealed and sold well. ${ }^{86}$

Thus we can see how the process of signification in tourist exchange was a good deal more complex than has been allowed in previous scholarship on Aboriginal tourist art. In Aboriginal Enterprises, as in Hermannsburg, public taste tended to prefer figurative and landscape imagery rather than a universalising modernist aesthetic of abstraction. This suggests that the relationship between a modernist aesthetic and design is also more complex than previously assumed. Moreover we see how Aboriginal artists at Hermannsburg, as in other more remote communities, maintained control over the highly valued, restricted knowledge encoded in their cultural forms, by substituting representational imagery which satisfied the market and protected the producer. ${ }^{87}$

\section{Contemporary perspectives}

It is clear that Aboriginal Enterprises achieved considerable success and widespread recognition nationally and internationally. During his lifetime Bill Onus, like Albert Namatjira, became a national figure celebrated as a symbol of successful assimilation - with all the contradictions this implied ${ }^{88}$ Yet the cultural production of Aboriginal Enterprises continues to be marginalised, bracketed off as tourist art. The reasons for this exclusion are multi-layered and interconnecting: in part an outcome of the authenticity paradigm governing colonial discourse; in part through dominant narratives of assimilation. Anna Haebich, in her book Spinning the Dream (2008), found that the Coolbaroo League in Perth, another

85 Kleinert 1994: 240.

86 Albrecht cited by Burn and Stephen 1999: 258.

87 Morphy 1980.

88 For the tensions and contradictions created for Albert Namatjira see Burn and Stephen 1992. 
Aboriginal initiative with many similarities to Aboriginal Enterprises, has met with a negative response from academics. In their response, the political goals of the organisation are 'rendered down', its activities interpreted as 'vehicles of assimilation' and the leaders categorised as 'cultural brokers' who are seen to have used their leadership to promote assimilation policies and further their own career. ${ }^{89}$ Likewise Aboriginal Enterprises was described pejoratively as a 'boomerang factory' devoid of any political goals while individuals who worked in tourism, theatre and film were seen to be 'exploiting their colour' ${ }^{90}$ The narrow frame imposed by these bleak views accords with the dominant historical narratives of the era that defined assimilation negatively in terms of a prevailing 'culture of poverty' approach. ${ }^{91}$ These responses suggest that for some, Bill Onus's status as symbol of successful assimilation contributed to the exclusion of Aboriginal Enterprises. But as this paper has shown, leaders like Doug Nicholls and Bill Onus pursued a political agenda aimed at fostering social cohesion and gaining respect and recognition for Aboriginal people. In the process they became powerful role models for Aboriginal people and their achievements created new opportunities for a 'cultural future'.

Since the 1970s a further radical shift has taken place. Contemporary Aboriginal artists with access to professional training and universities engage in revisionist histories that critique colonial stereotypes. Not surprisingly they look back upon the popular hybridity and fragmented histories of an earlier era with a degree of ambivalence. ${ }^{92}$ With earlier paradigms of authenticity called into question, the pervasive appropriation of the 1950s and 1960s is increasingly viewed as kitsch. Kitsch originated in the debates on authenticity and taste mounted in the 1930s and 1940s by the American formalist critic, Clement Greenberg in defence of high art under attack from the inroads of popular culture - in Greenberg's view 'an ersatz culture' that drew upon 'the debased and academicized simulacra of genuine culture' ${ }^{93}$ In contemporary art practice, kitsch is remorselessly critiqued by the ironic postmodern sensibility of Indigenous artists such as Gordon Bennett, Destiny Deacon and Christian Thompson. As Kirshenblatt-Gimblett points out, such a strategy allows that which is outmoded to be recuperated as a potentially radical gesture. ${ }^{94}$ In fact, kitsch highlights modernity's failure to acknowledge its egalitarian nature.

It would seem that rereading the historical record requires more than a 'fashionably ironic postmodern distancing' ${ }^{95}$ What is required, Phillips suggests, is more extensive postcolonial analysis of Indigenous cultural practice. This is to acknowledge the many creative interventions of Aboriginal people drawing from within their own resources and selectively implementing processes of adjustment, incorporation and collaboration in response to their colonial

89 Haebich does not cite references for this discussion (Haebich 2008: 298).

90 Barwick 1963: 339; Howie-Willis 2000: 538.

91 Langton 1981.

92 Haebich 2008: 337; Phillips 1998: 262, 265.

93 Greenberg 1973: 10.

94 Kirshenblatt-Gimblett 1998: 274.

95 Phillips 1998: xiii. 
experiences and the changing interests of the wider community. For some contemporary artists such as Lin Onus and Robert Campbell Jnr the basis of their cultural identity is to be found in these early experiences. Failure to acknowledge the Aboriginal ontologies that underpin cultural production in effect lends support for the cultural hierarchies that continue to exclude recognition for the history of Aboriginal art in south-eastern Australia.

\section{References}

\section{Newspapers}

The Christian Science Monitor

Herald

\section{Secondary sources}

Altman, Jon 1989, The Aboriginal Arts and Crafts Industry: Report to the Review Committee, Australian Government Publishing Service, Canberra.

Attwood, Bain 1989, The Making of the Aborigines, Allen \& Unwin, Sydney.

- 2003, Rights for Aborigines, Allen \& Unwin, Sydney.

Auld, Elizabeth 1957, 'Curtains can talk', TheNew Idea, 24 April 1957: 7.

'Australian seeks boomerang boom', 1955, The Christian Science Monitor, 22 October 1955: 7.

Barwick Dianne 1963, 'A Little More than Kin: Regional Affiliation and Group Identity among Aboriginal Migrants in Melbourne', unpublished PhD Thesis, The Australian National University, Canberra.

Bell, James 1967, 'The La Perouse Aborigines: A Study of their Group Life and Assimilation into Modern Australian Society', unpublished PhD Thesis, The University of Sydney, Sydney.

Bsumek, Erika Marie 2008, Indian-Made: Navajo Culture in the Market Place, 18681940, University Press of Kansas, Lawrence, Kansas.

Burn, Ian and Ann Stephen 1992, 'Namatjira's white mask: a partial interpretation', in The Heritage of Namatjira: the Watercolors of the Central Australia, Jane Hardy, JVS Megaw and M Ruth Megaw (eds), William Heinemann Australia, Port Melbourne: 249-282.

Craik, Jennifer 1998, 'Interpretative mismatch in cultural tourism', Tourism, Culture, and Communication 2(20): 115-128. 
Culler, Jonathon 1988, 'The semiotics of tourism', in Framing the Sign: Criticism and its Institutions, Basil Blackwell, London: 153-167.

Edmonds, Fran 2010, “"We have survived”: south east Australian Aboriginal art exhibitions since 1988', Recollections 5(1), April: unpaged.

Edwards, Deborah 2005, Margaret Preston, Art Gallery of New South Wales, Sydney.

Fry, Tony and Anne-Marie Willis 1989, 'Aboriginal art: symptom or success?', Art in America, July: 109-117, 159-160.

Ginsburg, Faye and Fred Myers 2006, 'A history of Aboriginal futures', Critique of Anthropology 26(1): 27-45.

Gough, Julie 2006a, 'Being collected and keeping it real', in Keeping culture: Aboriginal Tasmania, Amanda Jane Reynolds (ed), National Museum of Australia, Canberra: 9-20.

- 2006b, 'Being there, then and now: aspects of south-east Aboriginal art', in Landmarks, Judith Ryan (ed), National Gallery of Victoria, Melbourne: 125131.

Graburn, Nelson 1999, 'Epilogue: Ethnic and tourist arts revisited', in Unpacking Culture: Art and Commodity in Colonial and Postcolonial Worlds, Ruth B Phillips and Christopher Steiner (eds), University of California Press, Berkeley: 335354.

Greenberg, Clement 1973, Art and Culture, Thames and Hudson, London.

Haebich, Anna 1998 (reprint), For Their Own Good: Aborigines and Government in South West of Western Australia 1900-1940, University of Western Australia Press, Perth.

- 2008, Spinning the Dream: Assimilation in Australia 1950-1970, Fremantle Press, Fremantle, Western Australia.

- and Lauren Marsh 2008, 'Living the dream', in Spinning the Dream: Assimilation in Australia 1950-1970, Fremantle Press, Fremantle, Western Australia: 273301.

Hall, Lee-Anne 2004, 'Sitting down in the square: Indigenous presence in an Australian city', Humanities Research 11(1): 54-77.

Hall, Stuart 1990, 'Cultural identity and diaspora', in Identity: Community, Culture and Difference, Jonathon Rutherford (ed), Lawrence Wishart, London: 222-237. 
Howie-Willis, Ian 2000, 'William Townsend Onus (1906-1968)', Australian Dictionary of Biography, vol 15, 1940-1980, John Ritchie (ed), Melbourne University Press, Melbourne.

Hurst, Herschell 1955, 'Stone age legends in modern design: he tells tales of his own people', The Australian Home Beautiful, November 1955: 25-28.

Johnson, Vivien 1996, Copyrites: Aboriginal Art in the Age of Reproductive Technologies, National Indigenous Arts Advocacy Association, Sydney.

Jones, Phillip 1992, 'The boomerang's erratic flight: the mutability of ethnographic objects', in Power, Knowledge and Aborigines, Bain Atwood and J Arnold (eds), Special edition of Aboriginal Studies: 59-71.

Jules-Rosette, Bennetta 1984, The Message of Tourist Art: an African Semiotic System in Comparative Perspective, Plenum, London.

Kerin, Rani 2005, 'Charles Duguid and Aboriginal assimilation in Adelaide, 1950-1960', History Australia 2(2): 1-17.

Kinnane, Stephen and Brenda Croft 2003, 'Viewfinders and vignettes: Steve Kinnane in conversation with Brenda Croft', in South West Central: Indigenous Art from South Western Western Australia 1833-2002, Art Gallery of Western Australia: 15-20.

Kirshenblatt-Gimblett, Barbara 1998, Destination Culture: Tourism, Museums, and Heritage, University of California Press, Berkeley.

Kleinert, Sylvia 1994, “'Jacky Jacky was a smart young fella”: a Study of Art and Aboriginality in South East Australia 1900-1980', unpublished PhD Thesis, The Australian National University, Canberra.

- 1999, 'An Aboriginal Moomba: remaking history', Continuum: Journal of Media and Cultural Studies 13(3), November: 345-358.

- 2000, 'Rear vision mirror: a Koori context', in Urban Dingo: Lin Onus Retrospective, Queensland Art Gallery, South Brisbane: 25-31.

- 2006, 'Aboriginality in the city: re-reading Koori photography', Aboriginal History 30: 69-94.

- 2009, ‘Bill (William) Onus (1906-1968)', Dictionary of Australian Artists Online, $<$ www.daao.org.au>

Langton, Marcia 1981, 'Urbanizing Aborigines: the social scientists' great deception', Social Alternatives 2(2): 16-22. 
- 1993, 'Well I heard it on the radio and I saw it on the television ...' , Australian Broadcasting Commission, Sydney.

Lovett-Gardner, Iris 1997, Lady of the Lake: Aunty Iris's Story, Koorie Heritage Trust Melbourne.

Lydon, Jane 2005, Eye Contact: Photographing Indigenous Australians, Duke University Press, Durham

MacCannell, Dean 1992, Empty Meeting Grounds: the Tourist Papers, Routledge, New York.

McLean, Ian 1998, White Aborigines: Identity Politics in Australian Art, Cambridge University Press, Melbourne.

- 2009, 'Kura Alala: intersections between Indigenous and non-Indigenous artists', in Kura Alala Eyes Open: Tjanpi Desert Weavers, Maria Fernanda Cardoso, Alison Clouston, exhibition catalogue, Gold Coast City Gallery 17 October-6 December 2009: unpaged.

Miller, Mary Durack and Florence Rutter 1952, Child Artists of the Australian Bush, Australasian Publishing Company, Sydney.

Miller, Steve 2008, 'Designs on Aboriginal culture', in Modern Times: the Untold Story of Modernism in Australia, Ann Stephen, Philip Goad and Andrew McNamara (eds), Miegunyah Press, Melbourne: 30-35.

Moriarty, John and Evan McHugh 2000, Saltwater Fella, Viking, Ringwood, Victoria.

Morphy, Howard 1980, 'The impact of the commercial development of art on traditional culture', in Preserving Indigenous Cultures: a New Role for Museums, R Edwards and J Stewart (eds), Unesco and Aboriginal Arts Board of the Australia Council, Australian Government Publishing Service, Canberra: 81-94.

- 1991, Ancestral Connections: Art and an Aboriginal System of Knowledge, University of Chicago Press, Chicago.

- 1998, Aboriginal Art, Phaidon Press, London.

- 2008, Becoming Art: Exploring Cross Cultural Categories, University of New South Wales Press, Sydney.

Mountford, Charles 1956, Art, Myth and Symbolism, Records of the AmericanAustralian Scientific Expedition to Arnhem Land, vol 1, Melbourne University Press, Melbourne. 
Myers, Fred 1994, 'Culture-making: performing Aboriginality at the Asia Society Gallery', American Ethnologist 21(4): 679-699.

Nugent, Maria 2005, Botany Bay: Where Histories Meet, Allen \& Unwin, Crows Nest.

Onus, Lin 1990, 'Language and lasers', Art Monthly Australia Supplement, the Land, the City: the Emergence of Urban Aboriginal Art: 14-15, 19.

Phillips, Ruth B 1998, Trading Identities: the Souvenir in Native North American Art from the Northeast 1700-1900, University of Washington Press, Seattle.

- and Christopher B Steiner 1999, 'Art, authenticity and the baggage of colonial encounter', in Unpacking Culture: Art and Commodity in Colonial and Postcolonial Worlds, University of California Press, Berkeley: 3-19.

Pushman, Tracie and Robyn Smith Walley 2006, Koorah coolingah= Children Long Ago, University of Western Australia, Perth.

Rowse, Tim 2000, 'Transforming the notion of the urban Aborigine', Urban Policy and Research 18(2), June: 171-190.

- (ed) 2005, Contesting Assimilation, API Network, Perth.

Sayers, Andrew 1994, Aboriginal Artists of the Nineteenth Century, Oxford University Press, Melbourne.

Sculthorpe, Gaye 2000, 'When whitefellas go walkabout', in The Oxford Companion to Aboriginal Art and Culture, Sylvia Kleinert and Margo Neale (eds), Oxford University Press, Melbourne: 391-398.

Simpson, Colin 1951, Adam in Ochre: Inside Aboriginal Australia, Angus \& Robertson, Sydney.

Smyth, R Brough 1878, The Aborigines of Victoria and Other Parts of Australia and Tasmania, 2 Vols. John Ferres, London.

Stephen, Ann, Andrew McNamara and Philip Goad (eds) 2006, Modernism in Australia: Documents on Art, Design and Architecture 1917-1967, Miegunyah Press, Melbourne.

Stephen, Ann, Philip Goad and Andrew McNamara (eds) 2008, Modern times: the Untold Story of Modernism in Australia, Miegunyah Press, Melbourne.

Taffe, Sue 2001, 'Witnesses from the conference floor: oral history and the Federal Council for the Advancement of Aborigines and Torres Strait Islanders,' Journal of Australian Studies, 25(67): 9-21. 
Thomas, Nicholas 1999, Possessions: Indigenous Art/Colonial Culture, Thames and Hudson, London.

Tucker, Margaret 1977, If Everyone Cared: Autobiography of Margaret Tucker MBA, Ure Smith, Sydney. 